\title{
Temperature responses and calculated heat units for germi- nation of several range grasses and shrubs
}

\author{
GILBERT L. JORDAN AND MARSHALL R. HAFERKAMP
}

\section{Abstract}

Quantitative effects of temperature on germination were determined for 17 cool-season grasses, 19 warm-season grasses, and 18 miscellaneous forbs and shrubs associated with semiarid rangelands. These effects, expressed as the reciprocal of days to $50 \%$ germination, were used in linear regression analyses to predict the temperature at which the germination rate approaches zero from which heat units to $50 \%$ germination and germination indexes were derived. The regression relationships appeared to be linear if data were restricted to the lower range of germination temperatures. The germination rate approached zero at temperatures ranging from 3.7 to $6.3^{\circ} \mathrm{C}$ for cool-season and from 7.8 to $13.7^{\circ} \mathrm{C}$ for warm-season grasses. No particular trend was evident among the forbs and shrubs. The reciprocal of the slope of the regression equation was a constant expressing heat units to $50 \%$ germination. It was characteristic of each accession. The product of heat units and the zero rate temperature was used to calculate a germination index. This index compared well with selected germination responses observed in the field.

Key Words: germination rates, base temperature, germination indices, semiarid rangelands

Germination, a critical stage in establishment of seedlings on semiarid rangelands, is often limited by temperature even when moisture conditions are favorable. Quantitative temperature effects on germination may be useful to evaluate germination characteristics or establishment potential among range species. Derived variables such as heat units to $50 \%$ germination, temperatures coinciding with minimum germination rates, and products of the 2 germination indices should be helpful for explaining variations in seedling establishment observed in field plantings.

The heat unit concept relates a unique total of periodic temperatures summed above a minimum temperature. This is then related to a specific growth stage (Wang 1960), provided no other factors are limiting growth (Kish and Ogle 1980). Arnold (1959) stated the most critical factor in using heat units was the accurate determination of the minimum or base temperatures, and he discussed the use of linear regression equations for their prediction. He further indicated that the purpose of these minimum temperatures was to develop heat units, an expression of effective temperature, usually on a daily basis.

Schimpf et al. (1977) indicated germination rates are a more sensitive indicator of temperature effects on germination than are total germination percentages. Maguire (1962) and Czabator (1962) stated that species having similar total germination percentages may vary widely in rate of germination and consequent seeding value. Jordan (1983) illustrated that within a seed lot, establishment typically occurs on semiarid sites from seeds having the earliest germination. Methods used to express germination rates vary widely (Kotowski 1926, Czabator 1962, Tucker and

\footnotetext{
Authors are professor emeritus, range management, School of Renewable Natural Resources, University of Arizona, Tucson 85721; and plant physiologist, USDAAgricultural Research Service, Ft. Keogh, Rt. 1 Box 2021, Miles City, Mont. 59301.

This paper published with approval of the Director, Agricultural Experimental Station, College of Agriculture, University of Arizona, as Journal Paper No. 4034. Appreciation is expressed to Dr. T. Chester for statistical guidance.

Manuscript accepted 1 September 1988.
}

Wright 1965, Evetts and Burnside 1972). Therefore, published rates among species are not always related and easily compared. However, the germination rate index of Evetts and Burnside (1972), Pollack and Roos (1972), and the corrected germination rate of Hsu et al. (1985) are equivalent. Moreover, the data of Hsu et al. (1985) showed that dividing 100 by their corrected germination rate gave an approximation of time to $50 \%$ germination. Hegarty (1975) and Garcia-Huidobro et al. (1982a) showed a linear relationship between the reciprocal of time to $50 \%$ germination and certain optimum or lower germination temperatures. Angus et al. (1981) and Hsu et al. (1985) indicated this relationship was not linear, but it still gave the best estimate of the temperatures corresponding with minimum germination rate used to develop heat units and to characterize germination (Garcia-Huidobro et al. 1982a, Davidson and Campbell 1983).

It appears that quantitative temperature effects can be determined to characterize temperature-responsive germination rates. This paper reports on the determination of projected minimum temperatures, heat units, and germination rates for several rangeland species.

\section{Materials and Methods}

Seeds were obtained from commercial sources, from USDA Soil Conservation Service, Tucson Plant Materials Center, and from range sites identified by county and state. All seed lots were hand thrashed when necessary and further processed by air flotation to remove trash and poorly filled seeds.

Germination was conducted at constant temperatures in a germinator having forced-draft circulation. Light was not controlled, but was allowed to enter through the glass doors of the germinator. Three series of studies were conducted: cool-season grasses with 4 replications, warm-season grasses with 3 replications, and selected forbs and shrubs with 4 replications. Germination temperatures were 7,14 , and $21^{\circ} \mathrm{C}$ for cool-season grasses; 15,20 , and $30^{\circ} \mathrm{C}$ for warm-season grasses; and 5, 10, 20, and $30^{\circ} \mathrm{C}$ for forbs and shrubs. Replications for each species were completely randomized within the germinator for each temperature. For each replication 100 seeds were sprinkled into a 9-cm petri dish on Whatman ${ }^{1}$ No. 3 filter paper moistened with tap water.

Rapidly germinating seeds were observed for germination every 6 hours during the first week after imbibition began. Otherwise, seeds were observed every 12 hours for the first week, every day for the second week, and every 2 days thereafter up to a total of 60 days at low temperatures. Germinated seeds were counted, recorded, discarded, and water added when necessary. Seeds were considered germinated when the radicle was at least $1-\mathrm{mm}$ long. Germination was considered complete when no further germination occurred in 2 successive days.

Starting from the time imbibition began, the number of seeds germinated at each count was tabulated with the corresponding accumulated time. After each germination trial was completed,

\footnotetext{
Mention of a trademark or proprietary product does not constitute a guarantee or warranty of the product by U.S. Department of Agriculture or the University of Arizona and does not imply approval to the exclusion of other products that may also be suitable.
} 

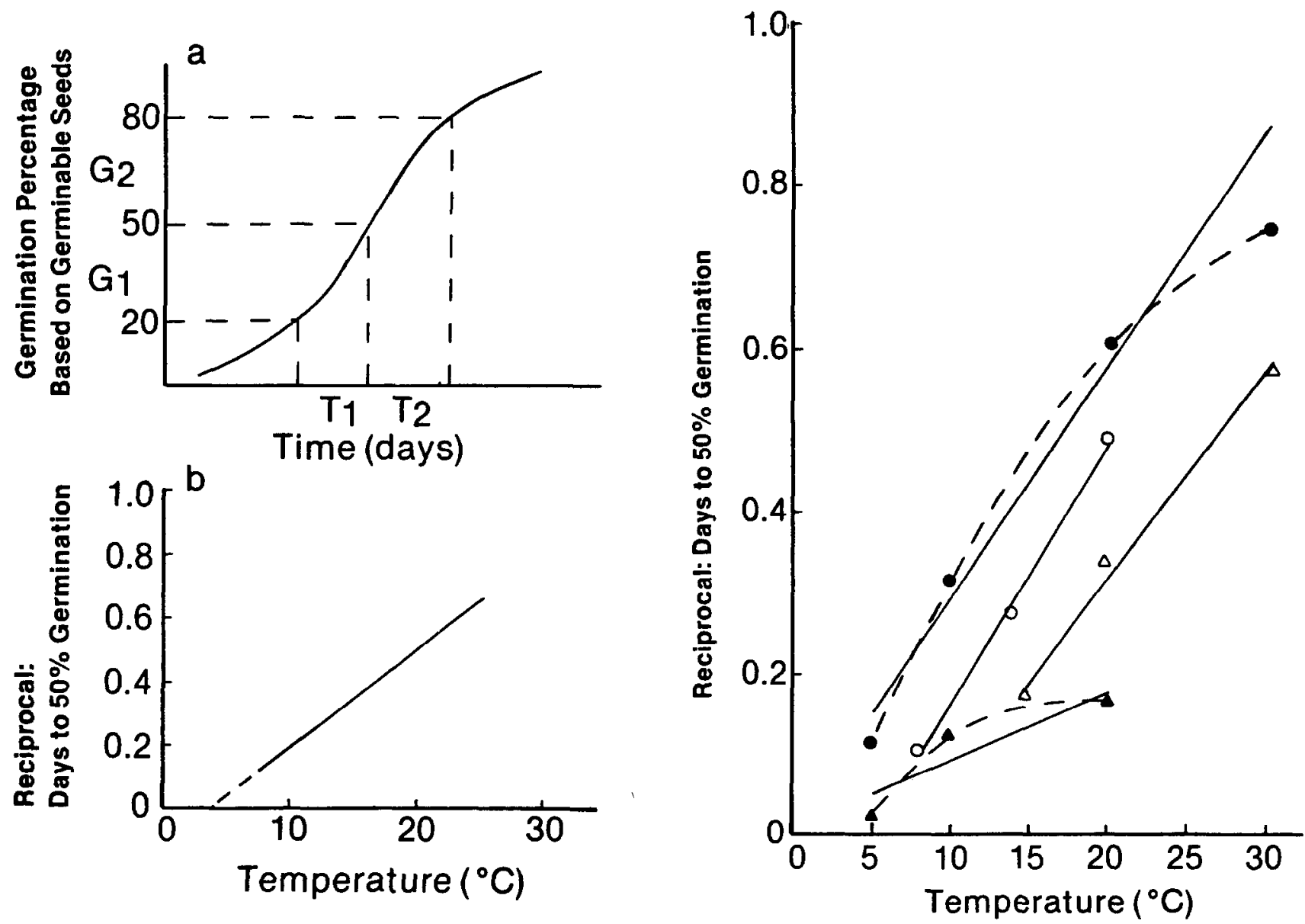

Fig. 1. (a) The linear portion of the S-shaped function of the germination curve used in equation (l) and (b) illustration of regression analysis and extrapolation used to determine temperature at which germination rate approached zero.

total percent germination was determined and each count was converted to percent germinable seed. Rate determinations were based on the equivalence of $\mathbf{1 0 0}$ germinable seeds for each accession. Time to $50 \%$ germination was calculated by equation (1) which restricts calculations to the linear portion of the S-shaped function of the germination curve (Fig. 1a).

$$
\text { Time to } 50 \% \text { germination }=T_{1}+\frac{50+G_{1}}{G_{2}-G_{1}} T_{2}-T_{1}
$$

where $\mathrm{G}_{1}=$ cumulative $\%$ germination between 20 and $50 \%$ at $\mathrm{T}_{1}$ and $\mathrm{G}_{2}=$ cumulative $\%$ germination between 50 and $80 \%$ at $T_{2}$

Regression analyses, both linear and quadratic, were conducted on each ecotype or species using the reciprocal of time to $50 \%$ germination as the dependent $(y)$ variable and temperature as the independent (x) variable (Fig. 1 b). If the quadratic function was significant, graphs were constructed and inspected to determine if some portion of the curve was sufficiently linear for further use (Fig. 2). Analyses of variance were also conducted on the linear and quadratic functions to determine which expressed the best relationship between temperatures and germination rates within species. When both linear and quadratic functions were significant $(P=0.05$ to 0.01 ), the percentage of total sums of squares contributing to each function was determined to further clarify this relationship (Snedecor 1956). Linear relationships are important for calculating the projected minimum temperature at which the germination rate is equal to zero. The minimum temperature was estimated by setting $y=0$ in

Fig. 2. The relationship of germination to temperatures for $\bullet$, Atriplex canescens; o, Bromus inermis; $\Delta$, Panicum antidotale; and $\mathbf{A}$, Ephedra viridis. Solid lines fitted from linear regression equations; dashed lines follow actual data where inhibitory high temperatures affected $\bullet$ and 4 .

the linear regression equation and solving for $x$ (Fig. Ib). Heat units/day, a measure of effective daily temperature (Arnold 1959), was calculated by equation (2).

Heats units $/$ day $=$ Mean daily temperature - Minimum temperature[2]

A heat unit index was calculated by equation (3).

Heat unit index $=($ Heat units $/$ day $) \times($ Days to $50 \%$ germination $)[3]$

The heat unit index is a constant for each species within favorable temperatures above the zero germination rate. It expresses heat units required to attain $50 \%$ germination, the reciprocal of which is used to determine the slope of the linear regression equation.

\section{Results and Discussion}

Coefficients of linear regression and levels of significance of the linear and quadratic regression analyses are presented in Table 1 for cool-season grasses, in Table 2 for warm-season grasses, and in Table 3 for forbs and shrubs. The linear component of regression was highly significant $(p=0.01)$ for all species. The quadratic component was generally not significant for various cultivars of grasses, but was generally highly significant $(p=0.01)$ for shrub ecotypes.

Even though Figure 2 illustrates a "worst case scenario", for certain species having a highly significant $(p=0.01)$ quadratic function (Tables 1, 2 and 3), visual inspection indicated linearity 
Table 1. Linear coefirients of determination, quadratic rezreacion sionificance, minimum germination rate temperatures, heat units to $50 \%$ germination and germination indices for selected cool-season range grasues. Linear regreasions were of the form $y=a+b x$ where $y=1 /$ days to $50 \%$ germination, $a=$ intercept, $b=$ slope, and $x=$ temperature.

\begin{tabular}{|c|c|c|c|c|c|c|}
\hline Species & $r^{2}$ & $\begin{array}{c}\text { Quadratic } \\
\text { significance } \\
\text { level }\end{array}$ & $\begin{array}{c}\% \\
\mathbf{s s}^{1}\end{array}$ & $\begin{array}{l}\text { Min. } \\
\text { temp. }\end{array}$ & $\begin{array}{l}\text { Heat } \\
\text { units }\end{array}$ & $\begin{array}{l}\text { Germ. } \\
\text { indices }\end{array}$ \\
\hline $\begin{array}{l}\text { Agropyron elongatum } \\
\text { 'Largo' }\end{array}$ & 0.995 & n.s. & & 4.3 & 30.2 & 130 \\
\hline $\begin{array}{l}\text { Agropyron elongatum } \\
\text { 'Jose' }\end{array}$ & 0.980 & n.s. & & 4.7 & 30.5 & 143 \\
\hline $\begin{array}{l}\text { Bromus inermis } \\
\text { 'Lincoln' }\end{array}$ & 0.985 & 0.01 & 0.8 & 4.9 & 31.0 & 152 \\
\hline $\begin{array}{l}\text { Elymus cinereus } \\
\text { "Coconio Co. Az. }\end{array}$ & 0.984 & n.s. & & 5.3 & 29.6 & 157 \\
\hline $\begin{array}{l}\text { Agropyron tricophorum } \\
\text { 'Luna' }\end{array}$ & 0.983 & 0.05 & 0.9 & 5.5 & 29.6 & 163 \\
\hline $\begin{array}{l}\text { Agropyron intermeditom } \\
\text { 'Tegmar' }\end{array}$ & 0.954 & n.s. & & 4.4 & 37.4 & 164 \\
\hline $\begin{array}{l}\text { Agropyron intermedium } \\
\text { 'Greenar' }\end{array}$ & 0.943 & n.s. & & 5.0 & 33.2 & 166 \\
\hline $\begin{array}{l}\text { Agropyron } \\
\text { dasystachyum } \\
\text { 'Critana' }\end{array}$ & 0.958 & n.s & & 4.5 & 41.3 & 186 \\
\hline $\begin{array}{l}\text { Agropyron riparium } \\
\text { 'Sodar' }\end{array}$ & 0.997 & 0.01 & 1.6 & 4.5 & 46.5 & 209 \\
\hline $\begin{array}{l}\text { Agropyron inerme } \\
\text { 'Whitmar' }\end{array}$ & 0.878 & 0.01 & 7.5 & 6.3 & 42.7 & 269 \\
\hline $\begin{array}{l}\text { Poa ampla } \\
\text { 'Sherman' }\end{array}$ & 0.989 & n.s. & & 3.7 & 72.9 & 269 \\
\hline $\begin{array}{l}\text { Agropyron desertorum } \\
\text { 'Nordan' }\end{array}$ & 0.971 & n.s. & & 4.8 & 60.9 & 292 \\
\hline $\begin{array}{l}\text { Agropyron cristatum } \\
\text { 'Fairway' }\end{array}$ & 0.943 & n.s. & & 5.0 & 62.9 & 314 \\
\hline $\begin{array}{l}\text { Elymus junceus } \\
\text { 'Vinall' }\end{array}$ & 0.970 & n.s. & & 5.8 & 58.6 & 340 \\
\hline $\begin{array}{l}\text { Agropyron smithii } \\
\text { commercial }\end{array}$ & 0.955 & n.s. & & 4.5 & 85.5 & 384 \\
\hline $\begin{array}{l}\text { Oryzopsis hymenoides } \\
\text { commercial }\end{array}$ & 0.848 & n.s. & & 4.7 & 87.5 & 411 \\
\hline $\begin{array}{l}\text { Elymus junceus } \\
\text { commercial }\end{array}$ & 0.960 & n.s. & & 5.0 & 90.6 & 453 \\
\hline
\end{tabular}

'Percentage sum of squares attributed to quadratic component of regression $P=0.05$ to 0.01 .

was not strongly affected until over 5 to $10 \%$ of the regression sum of squares was contributed by the quadratic function. The quadratic contribution was $0.8 \%$ for Bromus inermis, $7.0 \%$ for Atriplex canescens, $9.0 \%$ for Panicum antidotale, and $19.0 \%$ for Ephedra viridis. Linearity was deemed acceptable for the Bromus and Panicum selections, but not acceptable for Atriplex accessions because of obvious inhibition of rates above $20^{\circ} \mathrm{C}$. For Ephedra, linearity up to $20^{\circ} \mathrm{C}$ was not acceptable. Thus, rates for the latter 2 species, reported here for purposes of illustration, should be recalculated from germination studies conducted at a lower temperature range.

Aside from the few exceptions illustrated in Figure 2, relationships between the reciprocal of time to $50 \%$ germination and germination temperature were sufficiently linear over a wide array of species and ecotypes to allow calculation of projected times to $50 \%$ germination and temperatures associated with minimum germination rates. When heat units are included, the general requirements for germination of an accession can be characterized as for Poa ampla var. Sherman at $10^{\circ} \mathrm{C}$ (Table 1). The minimum temperature $3.7^{\circ} \mathrm{C}$ is subtracted from $10.0^{\circ} \mathrm{C}$ to obtain heat units/day, i.e., 6.3. When heat units to $50 \%$ germination (reciprocal of the slope b) are divided by heat units/day the quotient is equal to days to $50 \%$ germination at $10.0^{\circ} \mathrm{C}(72.9 / 6.3=11.5$ days $)$. Alternatively, regression coefficients -0.0507 (a) and 0.0137 (b) can be used to solve for $y$, the reciprocal of time to $50 \%$ germination
Table 2. Lnear coefficients of determination, quadratic regreasion aignifcance, minimum germination rate temperatures, heat units to $50 \%$ germination and germination indices for selected warm-season range grasses. Linear repreadions were of the form $y=a+b x$ where $y=1 /$ days to $50 \%$ germination, $a=$ intercept, $b=$ slope, and $x=$ temperature.

\begin{tabular}{|c|c|c|c|c|c|c|}
\hline Species & $r^{2}$ & $\begin{array}{c}\text { Quadratic } \\
\text { significance } \\
\text { level }\end{array}$ & $\begin{array}{c}\% \\
\text { ss }^{1}\end{array}$ & $\begin{array}{l}\text { Min. } \\
\text { temp. }\end{array}$ & $\begin{array}{l}\text { Heat } \\
\text { units }\end{array}$ & $\begin{array}{l}\text { Germ. } \\
\text { indices }\end{array}$ \\
\hline $\begin{array}{c}\text { Cenchrus ciliaris } \\
\mathbf{P}-15625^{2}\end{array}$ & 0.999 & n.s. & & 12.5 & 5.9 & 74 \\
\hline $\begin{array}{l}\text { Pennisetum setaceum } \\
\text { commercial }\end{array}$ & 0.999 & n.s. & & 11.0 & 6.7 & 74 \\
\hline $\begin{array}{l}\text { Bouteloua curtipendula } \\
\text { NM-28 }\end{array}$ & 0.993 & 0.05 & 0.5 & 8.9 & 8.5 & 76 \\
\hline $\begin{array}{l}\text { Bouteloua eriopoda } \\
\text { 'Sonora' }\end{array}$ & 0.992 & 0.01 & 0.5 & 13.0 & 5.9 & 77 \\
\hline $\begin{array}{l}\text { Leptochloa dubia } \\
\text { A-14254 }\end{array}$ & 0.964 & 0.05 & 3.0 & 13.0 & 6.9 & 90 \\
\hline $\begin{array}{l}\text { Setaria macrostachya } \\
\text { commercial }\end{array}$ & 0.879 & 0.01 & 11.8 & 11.1 & 8.3 & 92 \\
\hline $\begin{array}{l}\text { Bothriochloa ischaemum } \\
\text { P-15626 }\end{array}$ & 0.996 & n.s. & & 13.7 & 7.4 & 101 \\
\hline $\begin{array}{l}\text { Bouteloua gracilis } \\
\text { 'Hachita' }\end{array}$ & 0.975 & n.s. & & 10.6 & 10.0 & 106 \\
\hline $\begin{array}{l}\text { Eragrostis lehmanniana } \\
\times \text { E. tricophora } \\
\text { 'Cochise' }\end{array}$ & 0.998 & n.s. & & 10.2 & 10.6 & 108 \\
\hline $\begin{array}{l}\text { Eragrostis intermedia } \\
\text { A-19189 }\end{array}$ & 0.938 & n.s. & & 8.8 & 15.5 & 136 \\
\hline $\begin{array}{l}\text { Eragrostis lehmanniana } \\
\text { A-68 (lot 6101) }\end{array}$ & 0.994 & n.s. & & 10.8 & 12.8 & 138 \\
\hline $\begin{array}{l}\text { Digitaria califomica } \\
\text { A-16154 }\end{array}$ & 0.987 & 0.01 & 1.0 & 13.5 & 11.6 & 157 \\
\hline $\begin{array}{l}\text { Eragrostis curvula var. } \\
\text { conferta, 'Catalina' }\end{array}$ & 0.998 & n.s. & & 10.8 & 14.8 & 160 \\
\hline $\begin{array}{l}\text { Eragrostis lehmanniana } \\
\text { A-68 (lot 6092) }\end{array}$ & 0.937 & n.s. & & 13.4 & 12.4 & 166 \\
\hline $\begin{array}{l}\text { Sporobolus airoides } \\
\text { NM-184 }\end{array}$ & 0.999 & n.s. & & 12.0 & 16.0 & 192 \\
\hline $\begin{array}{l}\text { Eragrostis lehmanniana } \\
\text { L-19 }\end{array}$ & 0.993 & n.s. & & 12.4 & 16.9 & 210 \\
\hline $\begin{array}{l}\text { Panicum coloratum } \\
\text { commercial }\end{array}$ & 0.993 & n.s. & & 9.7 & 29.5 & 286 \\
\hline $\begin{array}{l}\text { Panicum antidotale } \\
\text { A-1 } 130\end{array}$ & 0.989 & 0.01 & 9.1 & 7.8 & 38.3 & 299 \\
\hline $\begin{array}{l}\text { Eragrostis curvula var. } \\
\text { conferta, A-84 }\end{array}$ & 0.998 & n.s. & & 11.2 & 39.7 & 445 \\
\hline
\end{tabular}

IPercentage sum of squares attributed to quadratic component of regression, $P=0.05$ to 0.01 .

${ }^{2}$ Numbers are accession numbers assigned by USDA, SCS, Plant Materials Center.

(Table 1). Quantitative evaluations of temperature have shown that 11.5 days at $10^{\circ} \mathrm{C}$ are required for germination of this species, but emergence would obviously require additional time. It is recognized, however, that these germination values are relative because field and laboratory responses will probably differ from one another.

Inhibition of germination rates by comparatively high temperature is considered to be the major cause of non-linearity in our study (Arnold 1959). When a highly significant quadratic component $(p=0.01)$ was present (Tables $1,2,3)$, higher germination temperatures demonstrated a higher requirement for heat units/ day than predicted by the use of the linear regression equation (Arnold 1959, Garcia-Huidobro et al. 1982a). Angus et al. (1981) used a similar heat unit study to estimate time to emergence for various field crops. They obtained non-linear relationships for some crops, but they could not improve on their estimates by non-linear models. Hsu et al. (1984) indicated that minimum germination temperatures, as used for determining germination rates in our study, were best estimated from linear regression analyses. 
Table 3. Linear coefícients of determinntion, quadratic regression significance, minimum germination rate temperatures, heat units to $50 \%$ germination and germination indices for selected forbs and shrubs. Linear regressions were of the form $y=a+b x$ where $y=1 /$ days to $50 \%$ germination, $a=$ intercept, $b=$ slope, and $x=$ temperature.

\begin{tabular}{|c|c|c|c|c|c|c|}
\hline Species & $r^{2}$ & $\begin{array}{c}\text { Quadratic } \\
\text { significance } \\
\text { level }\end{array}$ & $\begin{array}{l}\% \\
\text { ss }\end{array}$ & $\begin{array}{l}\text { Min. } \\
\text { temp. }\end{array}$ & $\begin{array}{l}\text { Heat } \\
\text { units i }\end{array}$ & $\begin{array}{l}\text { Germ. } \\
\text { indices }\end{array}$ \\
\hline $\begin{array}{l}\text { Ceratoides lanata } \\
\text { Cochise Co., Az. }\end{array}$ & 0.882 & 0.01 & 10.7 & 0.5 & 11.9 & 6 \\
\hline $\begin{array}{l}\text { Ceratoides lanata } \\
\text { Cochise Co., Az. }\end{array}$ & 0.970 & 0.01 & 10.7 & 1.2 & 17.3 & 21 \\
\hline $\begin{array}{l}\text { Baccharis sarothroides } \\
\text { Pima Co., Az. }\end{array}$ & 0.983 & 0.01 & 1.0 & 3.5 & 14.3 & 50 \\
\hline $\begin{array}{l}\text { Atriplex canescens } \\
\text { Millard Co., Utah }\end{array}$ & 0.885 & 0.01 & 7.1 & 1.5 & 38.5 & 58 \\
\hline $\begin{array}{l}\text { Ceratoides lanata } \\
\text { Garfield Co., Utah }\end{array}$ & 0.938 & n.s. & & 3.3 & 18.7 & 62 \\
\hline $\begin{array}{l}\text { Mimosa biuncifera } \\
\text { Gila Co., Az. }\end{array}$ & 0.784 & n.s. & & 1.4 & 71.5 & 100 \\
\hline $\begin{array}{l}\text { Cowania stansburiana } \\
\text { Coconino Co., Az. }\end{array}$ & 0.985 & 0.05 & 0.5 & 1.5 & 85.1 & 128 \\
\hline $\begin{array}{l}\text { Atriplex canescens } \\
\text { Rio Arriba Co., N.M. }\end{array}$ & 0.843 & 0.01 & 9.7 & 2.6 & 55.2 & 144 \\
\hline $\begin{array}{l}\text { Ephedra viridis } \\
\text { Sevier Co., Utah }\end{array}$ & 0.764 & 0.01 & 19.0 & 1.2 & 119.9 & 144 \\
\hline $\begin{array}{l}\text { Atriplex semibaccata } \\
\text { 'Corto' }\end{array}$ & 0.924 & 0.01 & 5.4 & 1.8 & 86.2 & 155 \\
\hline $\begin{array}{l}\text { Prosopsis juliflora } \\
\text { Pima Co., Az. }\end{array}$ & 0.948 & 0.01 & 4.0 & 10.3 & 17.4 & 179 \\
\hline $\begin{array}{l}\text { Cowania stansburiana } \\
\text { Yavapai Co., Az. }\end{array}$ & 0.987 & 0.01 & 0.9 & 1.1 & 172.2 & 182 \\
\hline $\begin{array}{l}\text { Fallugia paradoxa } \\
\text { Yavapai Co., Az. }\end{array}$ & 0.989 & 0.01 & 0.8 & 4.4 & 46.0 & 207 \\
\hline $\begin{array}{l}\text { Acacia greggii } \\
\text { Pinal Co., Az. }\end{array}$ & 0.985 & n.s. & & 7.2 & 29.3 & 211 \\
\hline $\begin{array}{l}\text { Larrea tridentata } \\
\text { Greenlee Co., Az. }\end{array}$ & 0.950 & 0.01 & 4.0 & 6.8 & 40.6 & 276 \\
\hline $\begin{array}{l}\text { Atriplex canescens } \\
\text { Pima Co., Az. }\end{array}$ & 0.984 & n.s. & & 9.0 & 34.9 & 314 \\
\hline $\begin{array}{l}\text { Ephedra viridis } \\
\text { Sanpete Co., Utah }\end{array}$ & 0.773 & 0.01 & 8.6 & 2.2 & 201.0 & 442 \\
\hline $\begin{array}{l}\text { Linum lewisii } \\
\text { 'Appar' }\end{array}$ & 0.828 & 0.01 & 15.0 & 3.2 & 174.3 & 558 \\
\hline
\end{tabular}

'Percentage sum of squares attributed to quadratic component of regression $P=0.05$ to 0.01 .

This approach proved valid even though some non-linearity was evident.

\section{Application of Projected Minimum Temperatures}

The projected minimum temperature is where the germination rate equals zero. Whether or not this projected temperature coincides with the physiological minimum temperature does not detract from the thesis that heat units can be used to characterize germination. The primary function of using base temperatures is to give the least variation among heat unit summations (Arnold 1959). Generally prediction of minimum temperatures and heat units will be more accurate when obtained from lower temperature ranges. Our studies also confirmed this trend. Moreover, when the minimum germination temperature was closely approached, time to accomplish germination increased. This may be critical in the field, particularly if germination time greatly exceeds the time that soil moisture is normally available. Data for $P$. ampla illustrates the principle. If the mean germination temperature was changed to $5^{\circ} \mathrm{C}$, the time to $50 \%$ germination would be 56 days, and at $4^{\circ} \mathrm{C}$ it would be 243 days. Projection of values beyond data used to establish the linear regression is obviously not valid. However, the general trend for long germination periods as minimum temperatures are approached is clearly established.
The apparent variation in minimum germination temperatures as reported in the literature is often due to differences in methodology or research objectives. Young and Evans (1982), for example, reported germination percentages of several cool-season grasses at lower temperatures than we measured (Table 1). Similarly, Coffman (1923) found wheat (Triticum aestivum) and other small grains would germinate at the temperature of melting ice. These endpoint temperatures differ from those determined as the germination rate equals zero. The germination rate of wheat approaches zero at $4.6^{\circ} \mathrm{C}$ (Davidson and Campbell 1983). Hsu et al. (1985) and Garcia-Huidobro et al. (1982a) reported temperatures associated with minimum germination rates for warm-season grasses that were within the range that we found (Table 2).

A marked trend occurred within plant classifications. Minimum temperatures were lower for cool- (Table 1) than for warm-season species (Table 2). Values ranged from 3.7 to $7.8^{\circ} \mathrm{C}$ for cool-season and from 7.8 to $13.7^{\circ} \mathrm{C}$ for warm-season species. This trend was not associated with the shrubs (Table 3). The species Larrea tridentata and Mimosa biuncifera had minimum temperatures of 6.8 and $1.4^{\circ} \mathrm{C}$, respectively. Both are warm-season shrubs. Moreoever, minimum temperatures for ecotypes of Atriplex canescens were $1.5,2.6$, and $9.0^{\circ} \mathrm{C}$ (Table 3), depending on location of seed collection sites. In contrast to the more uniform characteristics of released varieties, a wide variation in minimum temperatures may exist for wildland ecotypes.

Further research is needed to integrate the various factors affecting germination rates. Several examples of variations in temperature reponse are reported in the literature. Cluff et al. (1983) demonstrated that Distichlis spicata var. stricta would not germinate unless exposed to at least a $20^{\circ} \mathrm{C}$ diurnal temperature fluctuation. Young and Evans (1982), however, found maximum germination percentages could be obtained in constant temperatures for most of the cool-season grasses they studied. Finally, germination percentages and rates may vary among seed lots as well as plant ecotypes (Weaver and Jordan 1985).

\section{Heat Units and Germination Indexes}

Arnold (1959) defined the heat unit as a biologically effective temperature. Therefore, heat units are accumulated only during temperatures above a minimum (Holmes and Robertson 1958) and below a maximum that allow for growth processes of the target species (Garcia-Huidobro et al. 1982b). During a 10-year period, successful seedling emergence was observed from fall seeding on Artemisia tridentata sites only when mean monthly temperatures during the fall, winter and spring were above $0^{\circ} \mathrm{C}$, and 76 to 102 $\mathrm{mm}$ of effective precipitation occurred over the winter (Jordan 1983). Some species and cultivars consistently established more dependably than others. For example, in order of increasing establishment difficulty were Agropyron tricophorum var. Luna, $A$. desertorum var. Nordan, Elymus junceus var. Vinall, Oryzopsis hymenoides and $E$. junceus common. The trend for ease of establishment (Jordan 1981) was associated with low values of heat units required to attain $50 \%$ germination (Table 1). In addition, Arnold (1959) indicated the lower the minimum germination temperature the higher the germination efficiency. The cumulative effect of low heat unit values and low minimum temperature can be expressed as a germination index, equation (4).

Germination index $=($ Heat unit index $) \times$
(Minimum germination rate temperature)

For these 5 species, the respective heat unit indices were 163, 292, 340,411 , and 453.

Without knowledge of seedling drought tolerance, germination indices may not be as helpful for warm-as for cool-season grasses. Low indices, indicating high germination rates, may be a disadvantage on semiarid sites for establishment of selected species without 
high seedling drought tolerance. For example, $P$. antidotale and Eragrostis lehmanniana $\times E$. tricophora var. Cochise have been established on sites too arid for Bouteloua curtipendula (Jordan 1981 ), but their respective indexes were 299,108 , and 76 . Frasier et al. (1984) and Simanton and Jordan (1986) showed B. curtipendula seeds germinated rapidly. However, Frasier et al. (1984) found a high percentage of seedlings succumbed during the following dry period, whereas Cochise seeds germinated more slowly but had fewer dying during the dry period. These examples suggest seedling drought tolerance may be a necessary complement to high germination rates for successful establishment of selected grass species on rangelands where the amounts and timing of precipitation are sporadic.

In summary, heat units, germination indices, and germination rates can provide selection criteria among accessions within semiarid environments. These factors can be derived through regression analyses provided that the temperature range is restricted to an estimated 15 to $20^{\circ} \mathrm{C}$ above the temperature associated with the minimum germination rate. Observations made during this study indicate to obtain uniformity in reporting germination rates in the literature requires that germination temperatures must be determined accurately, equivalent end points of germination rates must be presented, and rates must be expressed only on basis of germinable seed.

Angus, J.F., R.B. Cunningham, M.W. Moncur, and D.H. Mackenzie. 1981. Phasic development in field crops. I. Thermal response in the seedling phase. Field Crops. Res. 3:365-378.

Arnold, C.Y. 1959. The determination and significance of the base temperature in a linear heat unit system. Proc. Amer. Soc. Hort. Sci. 74:430-445.

Cluff, G.J., R.A. Evans, and J.A. Young. 1983. Desert saltgrass seed germination and seedbed ecology. J. Range Manage. 36:419-422.

Coffman, F.A. 1923. The minimum temperature of germination of seeds. J. Amer. Soc. Agron. 15:257-270.

Czabator, F.J. 1962. Germination value: An index combining speed and completeness of pine seed germination. Forest Sci. 8:386-396.

Davidson, H.R., and C.A. Campbell. 1983. The effect of temperature, moisture and nitrogen on the rate of development of spring wheat as measured by degree days. Can. J. Plant Sci. 63:833-846.

Evetts, L.L., and O.C. Burnside. 1972. Germination and seedling development of common milkweed and other species. Weed Sci. 20:371-378.

Frasier, G.W., D.A. Woolhiser, and J.R. Cox. 1984. Emergence and seedling survival of two warm-season grasses as influenced by the timing of precipitation: A greenhouse study. J. Range Manage. 37:7-11.
Garcia-Huidobro, J., J.L. Monteith, and G.R. Squire. 1982a. Time, temperature and germination of pearl millet (Pennisetum typhoides S. \& H.) I.: Constant temperature. J. Exp. Bot. 33:288-296.

Garcin-Huidobro, J., J.L. Monteith, and G.R. Squire. 1982b. Time, temperature and germination of pearl millet (Pennisetum typhoides S. \& H) II. Alternating temperature. J. Exp. Bot. 33:297-302.

Hegarty, T.W. 1973. Temperature relations of germination in the field, $p$. 451-452. In: W. Heydecker (ed), Seed ecology. Penn State Univ. Press, University Park, Penn.

Holmes, R.M., and G.W. Robertson. 1959. Heat units and crop growth. Canada Dep. Agr. Pub. No. 1042.

Hsu, F.H., C.J. Nelson, and W.S. Chow. 1984. A mathematical model to utilize the logistic function in germination and seedling growth. J. Exp. Bot. 35:1629-1640.

Hsu, F.H., C.J. Nelson, and A.G. Matches. 1985. Temperature effects on germination of perennial warm-season grasses. Crop Sci. 25:215-220.

Jordan, G.L. 1981. Range seeding and brush management on Arizona rangelands. Univ. of Arizona, Agr. Exp. Sta. Tech. Bull. T81121.

Jordan, G.L. 1983. Planting limitations for arid, semiarid, and salt-desert shrublands, p. 11-16. In: S. Monsen and N. Shaw (compilers) Managing intermountain rangelands. 15-17 September 1981, Twin Falls, Idaho and 22-24 June 1982, Elko, Nevada. USDA Forest Service, Intermountain Res. Sta. Gen. Tech. Rep. INT-157.

Kish, A.J., and W.L. Ogle. 1980. Improving the heat unit system in predicting maturity date of snap beans. Hort. Sci. 15:140-141.

Kotowski, F. 1926. Temperature relations to germination of vegetable seeds. Proc. Amer. Soc. Hort Sci. 23:176-184.

Maguire, J.D. 1962. Speed of germination-aid in selection and evaluation for seedling emergence and vigor. Crop Sci. 2:176.

Pollack, B.M., and E.E. Roos. 1972. Seed and seedling vigor, p. 313-387. In: T.T. Kozlowski (ed.) Seed biology. Academic Press, New York, NY.

Schimpf, D.J., S.D. Flint, and I.G. Palmblad. 1977. Representation of germination curves with the logistic function. Ann. Bot. 41:1357-1360.

Simanton, J.R., and G.L. Jordan. 1986. Early root and shoot elongation of selected warm-season grasses. J. Range Manage. 39:63-67.

Snedecor, G.W. 1956. Statistical methods. Iowa State Univ. Press. Ames, lowa.

Tucker, H., and L.N. Wright. 1965. Estimating rapidity of germination. Crop Sci. 5:398-399.

Wang, J.Y. 1960. A critique of the heat unit approach to plant response studies. Ecology 41:785-790.

Weaver, L.C., and G.L. Jordan. 1985. Effects of selected seed treatments on germination rates of five range plants. J. Range Manage. 38:415-418.

Young, J.A., and R.A. Evans. 1982. Temperature profiles for germination of cool season range grasses. USDA, ARS, Agr. Res. Results. AAR-W27, Oakland, Calif. 